\title{
Renal Gluconeogenesis
}

\section{THE EFFECT OF DIET ON THE GLUCONEOGENIC CAPACITY OF RAT-KIDNEY-CORTEX SLICES}

\author{
By H. A. KREBS, D. A. H. BENNETT, P. DE GASQUET, T. GASCOYNE AND T. YOSHIDA \\ Medical Research Council Unit for Research in Cell Metabolism, Department of Biochemistry, \\ University of Oxford
}

(Received 16 July 1962)

Gluconeogenesis is known to occur not only in the liver but also in kidney cortex. Renal gluconeogenesis from lactate, pyruvate, amino acids and intermediates of the tricarboxylic acid cycle was first observed in tissue slices by Benoy \& Elliott (1937) and later confirmed by Weil-Malherbe (1938), Russell \& Wilhelmi (1941), Barron, Lyman, Lipton \& Goldinger (1941), Shipley (1944), and Teng $(1954 a, b)$. Evidence of gluconeogenesis in the kidney in situ was obtained on eviscerated animals by Bergman \& Drury (1938), Reinecke (1943), Reinecke \& Roberts (1944), Roberts \& Samuels (1944), Drury, Wick \& MacKay (1950) and McCann \& Jude (1958).

As an experimental material for the study of gluconeogenesis, the kidney offers major advantages over the liver. The content of preformed carbohydrate is much lower in kidney than in the liver. Liver of well-fed rats may contain more than $10 \%$ (wt./wet wt.) of glycogen and more than $0.5 \%$ (wt./wet wt.) of glucose. The corresponding values for rat kidney are $0.01 \%$ of glycogen and $0.05 \%$ of glucose (Marsh \& Miller, 1953; and our own measurements). Thus it is difficult to measure in the liver the net carbohydrate increases which occur after incubation for 1 or $2 \mathrm{hr}$. with precursors even when the preformed store of carbohydrate has been reduced by starvation. By contrast the increment of carbohydrate in kidney on incubation is relatively large.

The end product of gluconeogenesis in kidney is glucose rather than glycogen because the quantities of glycogen which can be stored in the kidney are very small, as shown by the observations of Froesch, Ashmore \& Renold (1958). In kidney the glycogen content of normal rats rose from $0.48 \mathrm{mg}$./ g. wet wt. to $1 \cdot 0-1.5 \mathrm{mg}$./g. wet wt. after continued glucose infusion into the blood stream. Under the same conditions the liver glycogen value rose from $22 \mathrm{mg}$./g. wet wt. to $106-137 \mathrm{mg}$./g. Per unit of weight, liver thus stored about 100 times as much glycogen as kidney.

The present paper is concerned with measurements of the rates of gluconeogenesis from various precursors and the effects of the diet of rats and the composition of the medium on the rates. Slices were used as the standard material because other tissue preparations failed to give high rates, for reasons which became obvious during the investigations.

\section{EXPERIMENTAL}

\section{Treatment of tissue}

Slices were cut free-hand by the method of Deutsch (1935). Usually a wet razor-blade was used and the slices were gently shaken for a few minutes in a saline medium (low in bicarbonate) at room temperature. This led to a loss of most of the preformed glucose. In some experiments where the initial glucose and glycogen contents were to be measured, slices were cut with a dry razor and the slices were weighed on a torsion balance. Incubation was at $40^{\circ}$ in the saline medium of $\mathrm{Krebs} \&$ Henseleit (1932) with $\mathrm{O}_{2}+\mathrm{CO}_{2}(95: 5)$ as the gas phase. Usually not more than $10 \mathrm{mg}$. of tissue (dry wt.) was suspended in $4 \mathrm{ml}$. of the medium and shaken for $\mathbf{l} \mathrm{hr}$. in a conical Warburg vessel. Modifications in the composition of the medium which were made to test the importance of individual ions are stated in the description of the experiments. At the end of the incubation the slices were removed and weighed after drying at $110^{\circ}$. The glucose in the solution was determined by the glucose-oxidase method. Preliminary experiments indicated that the amounts of glucose or glycogen in the tissue were usually negligible compared with the glucose content of the medium, and that glyoogen was not discharged into the medium. Many tests were carried out in duplicate.

\section{Analytical methods}

Assay of glucose. Glucose was determined by the glucoseoxidase method (Keilin \& Hartree, 1945, 1948) because of its high degree of specificity. The procedure adopted after many trials was based on those described by Huggett \& Nixon (1957) and Jakobsen (1960). The methods of Miller \& Van Slyke (1936) and Kingsley \& Reinhold (1949) gave 20$50 \%$ higher values.

The reagents required were: $3 \mathrm{~N}-\mathrm{HClO}_{4}$, prepared by diluting the commercial ' $60 \%$ ' solution (which contains $923 \mathrm{~g}$. of $\mathrm{HClO}_{4} / 1$.) with 2 vol. of water; $0.5 \mathrm{M}$-sodium phosphate buffer, pH 7.0, prepared by mixing 4 parts of $0.5 \mathrm{M}$ $\mathrm{Na}_{2} \mathrm{HPO}_{4}$ and 1 part of $0.5 \mathrm{M}-\mathrm{NaH}_{2} \mathrm{PO}_{4} ; 1 \%(\mathrm{w} / \mathrm{v}) 0$. dianisidine in $95 \%(v / v)$ ethanol (which keeps for a few weeks in the dark); glucose-oxidase reagent prepared daily from $125 \mathrm{mg}$. of glucose oxidase (crude) (from Sigma Chemical Co.), $4 \mathrm{mg}$. of peroxidase (pure) (from C. F. 
Boehringer und Soehne G.m.b.H.), $100 \mathrm{ml}$. of phosphate buffer and $0.5 \mathrm{ml}$. of 0 -dianisidine solution. Usually $1 \mathrm{ml}$. of solution, containing $0 \cdot 1-0 \cdot 8 \mu$ mole of glucose, was mixed with $1 \mathrm{ml}$. of water and $0.2 \mathrm{ml}$. of $3 \mathrm{~N}-\mathrm{HClO}_{4}$. When the glucose concentration of the unknown solution was very low, $2 \mathrm{ml}$. was used and water was omitted. After not less than $5 \mathrm{~min}$. the mixture was centrifuged and $1 \mathrm{ml}$. of the supernatant was mixed in a $10 \mathrm{ml}$. stoppered tube with $2.5 \mathrm{ml}$. of the glucose-oxidase reagent, and incubated for $1 \mathrm{hr}$. at $37^{\circ}$. The extinction was then measured in glass cuvettes at $440 \mathrm{~m} \mu$. A standard curve was made for each set of determinations by replacing the unknown solution with $1,1.5$ and $2.0 \mathrm{ml}$. of a glucose stock solution containing $1 \mathrm{mg} . / \mathrm{ml}$. These stock solutions were diluted to $50 \mathrm{ml}$.; $2 \mathrm{ml}$. of the diluted solutions were mixed with $0.2 \mathrm{ml}$. of the $3 \mathrm{~N}-\mathrm{HClO}_{4}$ solution and $1 \mathrm{ml}$. of this mixture was treated in the same way as $1 \mathrm{ml}$. of supernatant. Tests showed that the inorganic constituents of the saline medium did not affect the standard curve (see Salomon \& Johnson, 1959).

A special feature of this procedure compared with others is the use of $\mathrm{HClO}_{4}$ as a deproteinizing agent and the non-removal of the excess of the acid. Allowance is made in the buffer used in the enzyme reagent for the neutralization of the $\mathrm{HClO}_{4}$.

Assay of glycogen. Glycogen was determined as glucose after enzymic hydrolysis by a commercial enzyme preparation (Diazyme, of Takamine Products, Miles Chemical Co., Clifton, N.J.) prepared from Aspergillus (see Pazur \& Ando, 1959, 1960). The enzyme produces glucose from glycogen, starch, dextrins, maltose and intermediate oligosaccharides. It hydrolyses $\alpha-(1 \rightarrow 6)$-linkages as well as $\alpha-(1 \rightarrow 4)$-linkages but is stated to be low in transglucosidase activity. It contains traces of invertase. Glycogen was isolated by the method of Good, Kramer \& Somogyi (1933) and dissolved in water. In the present work the required value was in many cases total carbohydrate rather than glycogen and in these cases glycogen was not isolated. According to the manufacturers, 1 unit of Diazyme forms from starch under standard conditions $1 \mathrm{~g}$. of glucose $/ \mathrm{hr}$., and $1 \mathrm{~g}$. of Diazyme is adjusted to contain 160 units. The enzyme can thus form 160 times its own weight of glucose/ hr.

The $\mathrm{pH}$ of the sample to be analysed-either a solution or a homogenate or slices suspended in an aqueous mediumwas roughly adjusted to 4.4 with $\mathrm{N}-\mathrm{HCl}$ or $\mathrm{N}-\mathrm{NaOH}$, and for accurate adjustment sufficient $\mathrm{M}$-acetate buffer, $\mathrm{pH} 4 \cdot 4$ ( 2 parts of acetic acid and 1 part sodium acetate), was added to bring the final buffer concentration to $0.05 \mathrm{M}$. The amount of Diazyme used was about $0.2 \mathrm{mg} . / 100 \mu \mathrm{g}$. of glycogen; it was added in the form of an aq. $0.1 \%$ solution. An excess of Diazyme is undesirable because the enzyme preparation contains small quantities of apparent glucose or glucose precursors. The mixture was incubated for $90 \mathrm{~min}$. at $50^{\circ}$. It was then cooled and protein was precipitated by the addition of 0.1 vol. of $3 \mathrm{~N}-\mathrm{HClO}_{4}$. This mixture was further diluted with $0.27 \mathrm{~N}-\mathrm{HClO}$, to obtain a solution containing between 10 and $40 \mu \mathrm{g}$. of glucose $/ \mathrm{ml}$. Glucose was determined in $1 \mathrm{ml}$. of this material as described above. A control determined the blank glucose value.

The analysis of various samples of glycogen supplied by British Drug Houses Ltd., and of samples of Ascaris glycogen and of the liver of a case of 'glycogen storage disease', gave a yield of $90-95 \%$ which was not increased by repre- cipitation of the glycogen with ethanol. Somewhat incomplete yields of the same order of the enzymic degradation of glycogen by enzyme mixtures have also been observed by Gunja, Manners \& Khin Maung (1961).

Assay of L-lactic acid. L-Lactic acid was determined by an enzymic method based on that described by Lehmann (1938) and on information obtained from S. R. Elsden (personal communication). The main modification is the replacement of ferricyanide as hydrogen acceptor by 2,6 dichlorophenol-indophenol, which increases the sensitivity about 10 times.

Lactate dehydrogenase was prepared from baker's yeast as described by Boeri, Cutolo, Luzzati \& Tosi (1955). This gave an enzyme solution in neutral phosphate buffer containing EDTA (1 mM). Other reagents required are: $0.1 \mathrm{M}$ sodium phosphate buffer, $\mathrm{pH} \mathrm{7.4;10} \mathrm{mM-HCN} \mathrm{(65} \mathrm{mg.} \mathrm{of}$ KCN dissolved in $1 \mathrm{ml}$. of $\mathrm{N}-\mathrm{HCl}$ and $10 \mathrm{ml}$. of $0.1 \mathrm{M}$ sodium phosphate buffer, $\mathrm{pH} \mathbf{7 \cdot 4}$, and diluted with water to $100 \mathrm{ml}$.); 0.01\% 2,6-dichlorophenol-indophenol, freshly diluted from a $0.1 \%$ stock solution.

Deproteinization was carried out as described for the glucose determination. In $1 \mathrm{~cm}$. cuvettes were placed $1 \mathrm{ml}$. of deproteinized filtrate containing between 0.02 and $0.1 \mu$ mole of lactic acid, $0.5 \mathrm{ml}$. of phosphate buffer, $0.4 \mathrm{ml}$. of HCN solution, $0.5 \mathrm{ml}$. of dichlorophenol-indophenol, and water to $2.8 \mathrm{ml}$. After these solutions had been mixed, $0.2 \mathrm{ml}$. of lactate dehydrogenase solution was added and readings were started. When the enzyme activity was low, up to $\mathbf{0 . 5} \mathrm{ml}$. was used, in which case the amount of water was decreased to keep the total volume to $3 \mathrm{ml}$. Readings were taken every $2 \mathrm{~min}$. at $600 \mathrm{~m} \mu$ against a blank in which the test solution was replaced by water until the rates in test and blank were the same. An extinction change (corrected for the blank) of $\mathbf{0 . 5 3 0}$ corresponds to $0 \cdot 1 \mu$ mole of lactate. The reaction was usually completed within 10-20 min., depending on the amount of lactate and the activity of the enzyme. The blank usually moved about 0.1 in $20 \mathrm{~min}$.

\section{Experimental animals}

Wistar rats were used. Their standard food consisted of commercially available rat cubes [H. C. Styles (Bewdley) Ltd.] prepared according to the formula of Bruce \& Parkes (1949). This diet contains approximately $16 \%$ of crude protein, $5 \%$ of crude fibre, $3 \%$ of fat, $2.5 \%$ of minerals and $1 \%$ of vitamin supplements. The remainder is mainly carbohydrate derived from wholemeal flour and ground oats. When it was noted during the investigation that the carbohydrate content of the diet affects the gluconeogenic capacity of the tissues, various low-carbohydrate diets were used for limited periods, usually not exceeding 5 days. They consisted of casein (3 parts) and margarine (1 part) plus vitamin and mineral supplements, or casein alone with vitamin and mineral supplements, or cooked sheep heart.

\section{RESULTS}

Time-course of carbohydrate synthesis. Ratkidney-cortex slices, shaken in the presence of $\mathrm{L}$ lactate, formed glucose steadily for about $2 \mathrm{hr}$. During the third hour the rate decreased (Table 1). The determination of glycogen in parallel experiments showed that the glycogen content of the 
tissue fell slightly during the incubation but that this fall accounted for less than $5 \%$ of the glucose formed.

Effect of the ionic composition of the medium on the formation of glucose from lactate. The highest rates of glucose synthesis were obtained when the medium of Krebs \& Henseleit (1932) was used. Saline media which Buchanan, Hastings \& Nesbett $(1949 a, b)$ and Hastings, Teng, Nesbett \& Sinex (1952) found optimum for glycogen synthesis in liver proved inferior to the Krebs-Henseleit medium with kidney. The various media used by Teng $(1954 a, b)$ for kidney slices were also some-

Table 1. Time-course of the formation of glucose from lactate in rat-kidney-cortex slices

Experimental details are given in the text. About $10 \mathrm{mg}$. (dry wt.) was incubated with $0.01 \mathrm{M}-\mathrm{L}$-lactate at $40^{\circ}$.

$\begin{array}{cc}\begin{array}{c}\text { Time of } \\ \text { incubation } \\ \text { (min.) }\end{array} & \begin{array}{c}\text { Glucose found } \\ (\mu \text { moles/g. } \\ \text { dry wt./hr. })\end{array} \\ 0 & 5 \cdot 9 \\ 30 & 66 \\ 60 & 124 \\ 120 & 250 \\ 180 & 332\end{array}$

what inferior. The following variations of the medium only slightly modified the rate of gluconeogenesis from lactate: omission of phosphate or addition of sodium phosphate buffer $(0 \cdot 1 \mathrm{M}, \mathrm{pH} 7 \cdot 4)$ up to $8 \mathrm{mM}$ final concentration; omission of $\mathrm{Mg}^{2+}$ ions; omission of bicarbonate from the medium and of carbon dioxide from the gas mixture and absorbing the respiratory carbon dioxide by $2 \mathrm{~N}$-sodium hydroxide in the centre well. On the other hand omission of $\mathrm{Ca}^{2+}$ ions reduced the rate of glucose formation from lactate (and fumarate) $60-70 \%$ (Table 2); a Ca $\mathrm{Ca}^{2+}$ ion concentration of $2 \mathrm{mM}$ (the same as in blood serum) proved to be the optimum. Phosphate buffer at concentrations above $0.01 \mathrm{M}$ was inhibitory, probably because of the precipitation of $\mathrm{Ca}^{2+}$ ions.

Effect of diet. Replacement of the standard diet which contains about $73 \%$ of carbohydrate by a diet consisting of 3 parts of casein and 1 part of margarine, and containing only traces of carbohydrate, raised the rates of gluconeogenesis from various precursors substantially (Table 3 ). The increases were especially pronounced with Llactate, pyruvate, $\alpha$-oxoglutarate, L-glutamate, Lproline, fumarate and L-ornithine, and in the tissue not supplemented by a substrate. In these

Table 2. Effect of calcium ions on the rate of gluconeogenesis in rat-kidney-cortex slices

Experimental details are given in the text. Slices were incubated for $60 \mathrm{~min}$. in (a) Krebs-Henseleit saline or (b) the same medium without $\mathrm{CaCl}_{2}$. The substrate concentration was $0.01 \mathrm{M}$. The results are given as means \pm S.K.M. with the numbers of observations in parentheses.

\begin{tabular}{|c|c|c|c|}
\hline \multirow[b]{2}{*}{ Substrate } & \multicolumn{2}{|c|}{ Glucose formed ( $\mu$ moles/g. dry wt./hr.) } & \multirow{2}{*}{$\begin{array}{c}\text { Inhibition due } \\
\text { to absence } \\
\text { of } \mathrm{CaCl}_{2} \\
(\%)\end{array}$} \\
\hline & Standard saline & $\mathrm{CaCl}_{2}$-free saline & \\
\hline $\begin{array}{l}\text { L-Lactate } \\
\text { Fumarate }\end{array}$ & $\begin{array}{l}117 \pm 8 \cdot 4(5) \\
226 \pm 33(4)\end{array}$ & $\begin{array}{l}38 \pm 4 \cdot 5(5) \\
58 \pm 2 \cdot 1(4)\end{array}$ & $\begin{array}{l}69 \\
74\end{array}$ \\
\hline
\end{tabular}

Table 3. Effect of diet on the formation of glucose from various substrates in rat-kidney-cortex slices of young rats

Experimental details are given in the text. Young rats, 3-4 months old and weighing 110-250 g., were used. The low-carbohydrate diet was given for 3-5 days. Slices were incubated for $1 \mathrm{hr}$. The substrate concentration was $0.01 \mathrm{M}$. The results are given as means \pm S.F.M. with the numbers of observations in parentheses.

\begin{tabular}{|c|c|}
\hline $\begin{array}{l}\text { Substrate } \\
\text { added }\end{array}$ & $\begin{array}{l}\text { Standard } \\
\text { mixed diet }\end{array}$ \\
\hline $\begin{array}{l}\text { None } \\
\text { L-Lactate } \\
\text { Pyruvate } \\
\text { Fumarate } \\
\text { Succinate } \\
\text { Glycerol } \\
\alpha \text {-Glycerophosphate } \\
\text { Oxaloacetate } \\
\alpha \text {-Oxoglutarate } \\
\text { L-Aspartate } \\
\text { L-Glutamate } \\
\text { L-Proline } \\
\text { L-Arginine } \\
\text { L-Ornithine }\end{array}$ & $\begin{array}{c}12 \cdot 6 \pm 1 \cdot 46(14 \\
110 \pm 3 \cdot 1(24) \\
225 \pm 14 \cdot 4(13) \\
208 \pm 16 \cdot 6(13) \\
310 \pm 18 \cdot 2(5) \\
151 \pm 9 \cdot 7(4) \\
113 \pm 4 \cdot 8(4) \\
164 \pm 14 \cdot 8(4) \\
220 \pm 20 \cdot 2(7) \\
90 \pm 13 \cdot 1(4) \\
157 \pm 30 \cdot 2(6) \\
62 \pm 2 \cdot 1(5) \\
23 \pm 1 \cdot 8(5) \\
36 \pm 11 \cdot 0(4)\end{array}$ \\
\hline
\end{tabular}

Low-carbohydrate
diet (casein-margarine)
$22 \cdot 8 \pm 1 \cdot 0(15)$
$200 \pm 4 \cdot 8(14)$
$450 \pm 23 \cdot 4(8)$
$361 \pm 18 \cdot 9(11)$
$433 \pm 18 \cdot 3(5)$
$186 \pm 10 \cdot 1(5)$
$127 \pm 3 \cdot 2(5)$
$248 \pm 13 \cdot 0(6)$
$425 \pm 17 \cdot 2(5)$
$112 \pm 11 \cdot 2(7)$
$263 \pm 12 \cdot 7(12)$
$146 \pm 8 \cdot 4(5)$
$37 \pm 2 \cdot 0(5)$
$66 \pm 4 \cdot 0(5)$

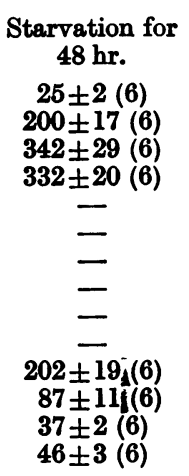


cases the increase was about $100 \%$. The effect of the diet was noticeable after 1 day and reached the maximum after 3 days. The results in Table 3 refer to young rats weighing $110-250 \mathrm{~g}$. Older rats aged 12-15 months and weighing 400-500 g. gave similar values (Table 4).

Diets consisting of casein only or of cooked sheep heart caused the same effect as the caseinmargarine mixture.

Starvation for $48 \mathrm{hr}$. also increased the rate of gluconeogenesis but substantially less so than the feeding of a casein-margarine diet, except when lactate or proline was the precursor (see Table 3).

Metabolism of glycogen in kidney cortex. As glycogen, unlike glucose, may be expected to remain within the slice, the measurement of glycogen metabolism requires an analysis of the slices. In order to determine both glycogen and glucose changes the slices, cut with a dry razor and weighed on a torsion balance, were analysed either directly or after incubation. In the latter case the slices were freed from the medium on filter paper before they

Table 4. Effect of diet on the formation of glucose from various substrates in rat-kidney-cortex slices of older rats

Experimental details are given in the text. Rats, aged 12-15 months and weighing 400-500 g., were used. The low-carbohydrate diet was given for 3-5 days. Slices were incubated for $1 \mathrm{hr}$. The substrate concentration was $0.01 \mathrm{M}$. The results are given as means \pm S.E.M. with the numbers of observations in parentheses.

\begin{tabular}{|c|c|c|}
\hline $\begin{array}{l}\text { Substrate } \\
\text { added }\end{array}$ & $\begin{array}{l}\text { Standard } \\
\text { mixed diet }\end{array}$ & $\begin{array}{c}\text { Low-carbohydrate } \\
\text { diet (casein- } \\
\text { margarine) }\end{array}$ \\
\hline $\begin{array}{l}\text { None } \\
\text { L-Lactate } \\
\text { Pyruvate } \\
\text { Fumarate } \\
\text { Sucoinate } \\
\text { Glycerol } \\
\text { Oxaloacetate } \\
\alpha \text {-Oxoglutarate } \\
\text { L-Aspartate } \\
\text { L-Glutamate }\end{array}$ & $\begin{array}{c}11 \cdot 2 \pm 1 \cdot 23(6) \\
97 \pm 10 \cdot 1(8) \\
250 \pm 26 \cdot 3(4) \\
273 \pm 16 \cdot 9(6) \\
286 \pm 18 \cdot 6(6) \\
97 \pm 9 \cdot 8(3) \\
155 \pm 11 \cdot 9(3) \\
248 \pm 20 \cdot 4(6) \\
33 \pm 4 \cdot 3(6) \\
137 \pm 10 \cdot 0(7)\end{array}$ & $\begin{array}{c}24 \cdot 6 \pm 4 \cdot 2(5) \\
181 \pm 23 \cdot 9(5) \\
404 \pm 50 \cdot 4(5) \\
355 \pm 21 \cdot 5(8) \\
293 \pm 38 \cdot 2(5) \\
140 \pm 20 \cdot 5(3) \\
203 \pm 17 \cdot 3(3) \\
340 \pm 20 \cdot 7(5) \\
73 \pm 5 \cdot 8(5) \\
269 \pm 16 \cdot 9(8)\end{array}$ \\
\hline
\end{tabular}

were placed in the potassium hydroxide solution as described by Good et al. (1933) for the glycogen determination, or into perchloric acid solution for the glucose determination. Results of an experiment in which lactate and fumarate served as substrates is shown in Table 5. Glycogen was formed in small quantities in the control to which no substrate was added as well as in the presence of lactate or fumarate. The absolute amounts of glycogen formed were almost independent of the substrate, so that glucose was virtually the only carbohydrate formed from the added substrate. The result is in agreement with previous findings (see Landau, 1960; Marsh \& Miller, 1953).

\section{DISCUSSION}

General comment. The main object of the experiments reported in this paper was to establish kidney cortex as a favourable material for the study of gluconeogenesis in vitro and to find the experimental conditions under which the process is optimum. Some advantages of kidney have already been summarized in the introduction. Others are the stability of the tissue in vitro over several hours, the high rate of metabolic activity, and the greater permeability to the anions of the di- and tri-carboxylic acids.

The rates of glucose formation reported in this paper are considerably higher than those recorded by others (see Table 6). The values of Russell \& Wilhelmi (1941) are the only ones which approach the present rates for rats fed on a standard diet (Tables 3 and 4). Those of Benoy \& Elliott (1937) are about $50 \%$ of the present values and those of Teng $(1954 a, b)$ and Landau (1960) only 15-20\%. The reason for the low values found by previous investigators is in all probability the inadequate oxygenation of the tissue. Teng used $400-700 \mathrm{mg}$. wet wt. in 3-4 ml. of medium and Landau 500$800 \mathrm{mg}$. in $8 \mathrm{ml}$. of medium. We used $30-50 \mathrm{mg}$. in $4 \mathrm{ml}$., after noting that the rates of gluconeogenesis fell when more tissue was used. In view of the high rate of respiration in the presence of gluco-

\section{Table 5. Formation of glucose and glycogen in rat-kidney-cortex slices}

Experimental details are given in the text. The rat was fed on the standard diet. The substrate concentration was $0.01 \mathrm{M}$. Incubation was for $1 \mathrm{hr}$. Glyoogen is expressed as glucose.

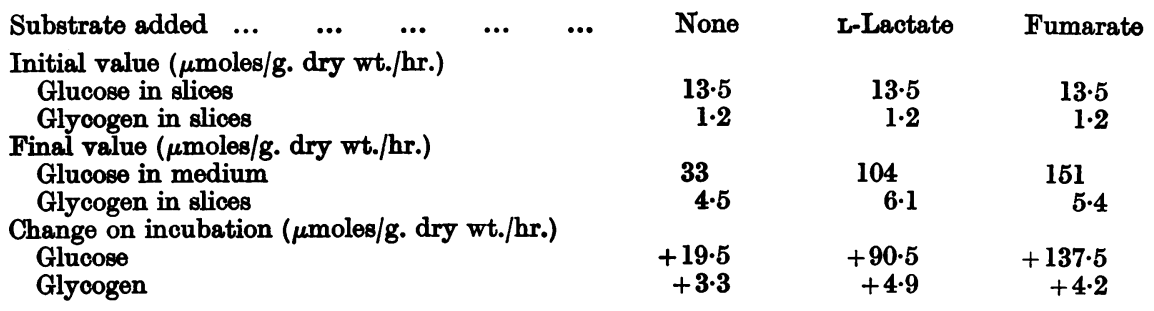


Table 6. Rates of gluconeogenesis in rat-kidneycortex slices observed by previous authors

The values quoted are representative. Where the original papers mentioned wet weight only the values obtained were multiplied by $4 \cdot 5$. The results refer to normal rats fed on standard diets. The slices were suspended in a saline medium at body temperature.

$\begin{array}{clc}\text { Author } & \text { Substrate } & \begin{array}{c}(\mu \mathrm{moles} / \mathrm{g} . \\ \text { dry wt. } / \mathrm{hr} .)\end{array} \\ \text { Benoy \& Elliott (1937) } & \text { DL-Lactate } & 50 \\ & \text { Pyruvate } & 160 \\ & \text { Succinate } & 70 \\ \text { Russell \& Wilhelmi } & \text { Pyruvate } & 160 \\ (1941) & \text { L-Glutamate } & 220 \\ & \text { Succinate } & 160 \\ \text { Teng }(1954 a, b) & \text { Pyruvate } & 30 \\ & \text { Glycerol } & 33 \\ \text { Landau }(1960) & \text { Pyruvate } & 35\end{array}$

neogenic substrate (about $2000 \mu$ moles/g. dry wt./ $\mathrm{hr}$.) this fall is not unexpected. The thinness of the slices is also of importance if the rate of oxygen supply is not to be a factor limiting the rate of gluconeogenesis.

The rates of glucose formation from lactate and pyruvate and some of the amino acids are comparable with those of glycolysis of many tissues. Brain, intestinal mucosa, testis, pancreas, salivary gland and diaphragm can glycolyse up to 100 $500 \mu$ moles of glucose/g. dry wt./hr. whereas kidney cortex can synthesize $450 \mu$ moles of glucose from pyruvate and $200 \mu$ moles from lactate in animals fed on a low-carbohydrate diet. It is noteworthy that the two tissues possessing the gluconeogenic enzyme systems-liver and kidney cortex (Benoy \& Elliott, 1937)-have very low rates of glycolysis. In kidney cortex the rate of gluconeogenesis from lactate or glutamate can be 3-4 times greater than that of glycolysis.

Role of calcium ions. The fact that $\mathrm{Ca}^{2+}$ ions are necessary for maximal rates of gluconeogenesis may explain why attempts to obtain gluconeogenesis in tissue homogenates have been essentially unsuccessful. Such gluconeogenesis as has been observed in homogenates (Dierks, 1957) represents only a fraction of the original capacity of the tissue. Gluconeogenesis depends on a supply of ATP, and the generation of ATP in homogenates is inhibited by the concentration of $\mathrm{Ca}^{2+}$ ions needed for maximum gluconeogenesis. Thus 'compartmentation', keeping enzymes dependent on $\mathrm{Ca}^{2+}$ ions and those requiring them apart, must be essential. It remains to be investigated which stage of gluconeogenesis requires the presence of $\mathrm{Ca}^{2+}$ ions.

Effect of diet. The response of the kidney to a low-carbohydrate diet is an adaptive reaction, adjusting the metabolism to the needs of the organism. That some enzymes involved in gluconeogenesis, e.g. glucose 6-phosphatase, increase their activity on a low-carbohydrate diet has been demonstrated by Freedland \& Harper $(1957,1958)$ and by Mokrasch, Davidson \& McGilvery (1956), who showed an increased activity of fructose 1,6diphosphatase after giving a low-carbohydrate diet or treatment with cortisone (see also Landau, Hastings \& Zottu, 1958). Long (1940) first showed that the gluconeogenic capacity of the body is under the control of the hormones of the adrenal cortex. Weber \& Macdonald (1961) have demonstrated the role of the diet and hormones in the control of the level of glucose 6-phosphatase, phosphohexoseisomerase and phosphoglucomutase activities.

Since Knox (1951) first demonstrated the adaptive formation of liver enzymes in response to the feeding of tryptophan, many cases of adaptation and enzyme induction have become known in animal tissues (e.g. Ashmore, Hastings, Nesbett \& Renold, 1956; Schimke, 1962). Gluconeogenesis, involving at least 11 enzymes when lactate is the starting material and at least 17 when proline is the precursor, may prove a useful system for studying the mechanism of, and the role of hormones in, adaptation, the 'co-ordinate repression' of enzymes (Ames \& Garry, 1959) and the identification of pacemaker steps (see also Monod \& Jacob, 1961).

Gluconeogenesis from amino acids. In rat-kidney cortex L-glutamate, L-aspartate, L-proline, Lornithine and L-arginine are the only $L$-amino acids that show rapid rates of gluconeogenesis (Tables 3 and 4; see also Russell \& Wilhelmi, 1941; Hanson, Lindsay \& Barker, 1961). Other amino acids known to be gluconeogenic in the whole organism yielded little or no glucose in rat-kidney cortex.

\section{SUMMARY}

1. The optimum conditions for the conversion of lactate, pyruvate, intermediates of the tricarboxylic acid cycle and amino acids into glucose in rat-kidney-cortex slices have been investigated. The balanced saline medium of Krebs \& Henseleit (1932) was found to give maximal values. The rates of gluconeogenesis were much higher than those observed by previous investigators. Pyruvate yielded up to $450 \mu \mathrm{moles}$ of glucose/g. dry wt./hr.

2. Reduction of the concentrations of bicarbonate, carbon dioxide or $\mathrm{Mg}^{2+}$ ions, or increasing the concentration of phosphate to $8 \mathrm{~mm}$, had no major effects on the rates of gluconeogenesis from lactate or fumarate, but omission of $\mathrm{Ca}^{2+}$ ions reduced the rate by about $70 \%$.

3. By keeping rats for 3-5 days on a diet low in carbohydrate the capacity of the tissue to syn- 
thesize glucose from various precursors was almost doubled.

4. Starvation (for $48 \mathrm{hr}$.) also increased the gluconeogenic capacity, but not as much as the low-carbohydrate diet.

5. Of the gluconeogenic amino acids only glutamate, aspartate, proline, ornithine and arginine yielded glucose rapidly.

6. An enzymic method for the determination of glycogen is described.

7. Several advantages of kidney cortex over liver as a material for the study of gluconeogenesis are pointed out; a major one is the low content of preformed carbohydrate.

This work was aided by grants from the Rockefeller Foundation and from the National Institutes of Health, United States Public Health Service.

\section{REFERENCES}

Ames, B. N. \& Garry, B. (1959). Proc. nat. Acad. Sci., Wash., 45, 1453.

Ashmore, J., Hastings, A. B., Nesbett, F. B. \& Renold, A. E. (1956). J. biol. Chem. 218, 77.

Barron, E. S. G., Lyman, C. M., Lipton, M. A. \& Goldinger, J. M. (1941). J. biol. Chem. 141, 957.

Benoy, M. P. \& Elliott, K. A. C. (1937). Biochem. J. 31, 1268.

Bergman, H. \& Drury, D. R. (1938). Amer. J. Physiol. 124, 279.

Boeri, E., Cutolo, E., Luzzati, M. \& Tosi, L. (1955). Arch. Biochem. Biophys. 56, 487.

Bruce, H. M. \& Parkes, A. J. (1949). J. Hyg., Camb., 47, 202.

Buchanan, J. M., Hastings, A. B. \& Nesbett, F. B. (1949a). J. biol. Chem. 180, 435.

Buchanan, J. M., Hastings, A. B. \& Nesbett, F. B. (1949b). J. biol. Chem. 180, 447.

Deutsch, W. (1935). J. Physiol. 87, 56 P.

Dierks, C. (1957). D.Phil. Thesis: University of Oxford.

Drury, D. R., Wick, A. N. \& MacKay, E. M. (1950). Amer. J. Physiol. 163, 655.

Freedland, R. A. \& Harper, A. E. (1957). J. biol. Chem. 228, 743.

Freedland, R. A. \& Harper, A. E. (1958). J. biol. Chem. 230, 833.

Froesch, E. R., Ashmore, J. \& Renold, A. E. (1958). Endocrinology, 62, 614.
Good, C. A., Kramer, H. \& Somogyi, M. (1933). J. biol. Chem. 100, 485.

Gunja, Z. H., Manners, D. H. \& Khin Maung (1961). Biochem. J. 81, 392

Hanson, R. W., Lindsay, R. H. \& Barker, S. B. (1961). Endocrinology, 69, 883.

Hastings, A. B., Teng, C. T., Nesbett, F. B. \& Sinex, F. M. (1952). J. biol. Chem. 194, 69.

Huggett, A. St G. \& Nixon, D. A. (1957). Lancet, ii, 368.

Jakobsen, L. K. (1960). Scand. J. clin. Lab. Invest. 12, 76.

Keilin, D. \& Hartree, E. F. (1945). Biochem. J. 39, 293.

Keilin, D. \& Hartree, E. F. (1948). Biochem. J. 42, 230.

Kingsley, G. R. \& Reinhold, J. G. (1949). J. Lab. clin. Med. 84, 713.

Knox, W. E. (1951). Brit. J. exp. Path. 32, 462.

Krebs, H. A. \& Henseleit, K. (1932). Hoppe-Seyl. Z. 210, 33.

Landau, B. R. (1960). Endocrinology, 67, 744.

Landau, B. R., Hastings, A. B. \& Zottu, S. (1958). J. biol. Chem. 233, 1257.

Lehmann, J. (1938). Scand. Arch. Physiol. 80, 237.

Long, C. N. H. (1940). Endocrinology, 26, 309.

McCann, W. P. \& Jude, J. R. (1958). Bull. Johns Hopk. Hosp. 108, 77.

Marsh, J. B. \& Miller, K. L. (1953). Science, 118, 416.

Miller, B. F. \& Van Slyke, D. D. (1936). J. biol. Chem. 114, 583.

Mokrasch, L. C., Davidson, W. D. \& McGilvery, R. W. (1956). J. biol. Chem. 222, 179.

Monod, J. \& Jacob, F. (1961). Cold Spr. Harb. Symp. quant. Biol. 26, 389.

Pazur, J. H. \& Ando, T. (1959). J. biol. Chem. 234, 1966.

Pazur, J. H. \& Ando, T. (1960). J. biol. Chem. 235, 297.

Reinecke, R. M. (1943). Amer. J. Physiol. 140, 276.

Reinecke, R. M. \& Roberts, S. (1944). Amer. J. Physiol. 141, 476.

Roberts, S. \& Samuels, L. T. (1944). Amer. J. Physiol. 142, 240.

Russell, J. A. \& Wilhelmi, A. E. (1941). J. biol. Chem. 140, 747.

Salomon, L. L. \& Johnson, J. E. (1959). Analyt. Chem. 31, 453.

Schimke, R. T. (1962). J. biol. Chem. 237, 459.

Shipley, R. A. (1944). Amer. J. Physiol. 141, 662.

Teng, C. T. (1954a). Arch. Biochem. Biophys. 48, 409.

Teng, C. T. (1954b). Arch. Biochem. Biophys. 48, 415.

Weber, G. \& Macdonald, H. (1961). Exp. Cell Res. 22, 292.

Weil-Malherbe, H. (1938). Biochem. J. 32, 2276. 